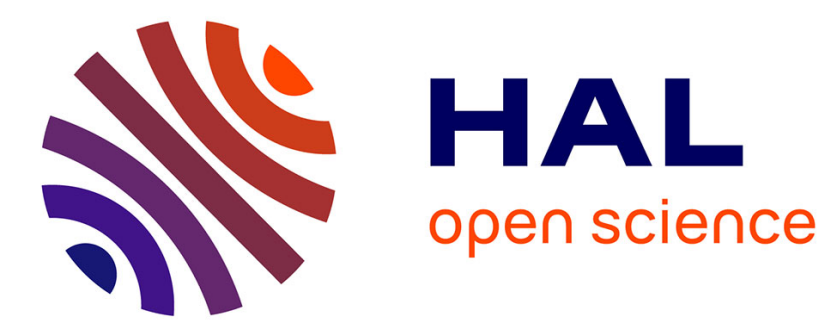

\title{
PCSK9: from biology to clinical applications
}

\author{
Valentin Blanchard, Ilya Khantalin, Stéphane Ramin-Mangata, Kévin \\ Chémello, Brice Nativel, Gilles Lambert
}

\section{To cite this version:}

Valentin Blanchard, Ilya Khantalin, Stéphane Ramin-Mangata, Kévin Chémello, Brice Nativel, et al.. PCSK9: from biology to clinical applications. Pathology, 2019, 51, pp.177 - 183. 10.1016/j.pathol.2018.10.012 . hal-03485627

\section{HAL Id: hal-03485627 \\ https://hal.science/hal-03485627}

Submitted on 20 Dec 2021

HAL is a multi-disciplinary open access archive for the deposit and dissemination of scientific research documents, whether they are published or not. The documents may come from teaching and research institutions in France or abroad, or from public or private research centers.
L'archive ouverte pluridisciplinaire HAL, est destinée au dépôt et à la diffusion de documents scientifiques de niveau recherche, publiés ou non, émanant des établissements d'enseignement et de recherche français ou étrangers, des laboratoires publics ou privés.

\section{다)(1) $(5$}

Distributed under a Creative Commons Attribution - NonCommerciall 4.0 International 


\section{PCSK9: from biology to clinical applications}

Authors: Valentin Blanchard ${ }^{1}$, Ilya Khantalin ${ }^{1,2}$, Stéphane Ramin-Mangata ${ }^{1}$, Kévin Chémello $^{1}$, Brice Nativel ${ }^{1}$, and Gilles Lambert ${ }^{1}$

Affiliations: (1) Laboratoire Inserm UMR 1188 DéTROI, Université de La Réunion, SainteClotilde, FRANCE ; (2) CHU de La Réunion, Service de Chirurgie Vasculaire, Saint-Denis, FRANCE.

Corresponding author: Valentin Blanchard and Gilles Lambert, Inserm UMR 1188, Plateforme CYROI, 2 Rue Maxime Rivière, 97490 Sainte Clotilde, France. Tel: + 262692 437 708; Fax: +262 262938 237; E-mail: valentin.blanchard@univ-reunion.fr and gilles.lambert@univ-reunion.fr.

Running title: PCSK9 biology. 
Pathology

\begin{abstract}
Proprotein convertase subtilisin/kexin type 9 (PCSK9) is a crucial protein governing the circulating levels of LDL-cholesterol (LDL-C), by virtue of its pivotal role in the degradation of the LDL receptor (LDLR). In the last 15 years, in vitro and in vivo studies have allowed our understanding of the physiological role of PCSK9. In the current report, we review the key studies that have established the mode of action of PCSK9, leading to the development of PCSK9 inhibitors for clinical use. Data from clinical trials investigating these therapies clearly and unambiguously demonstrate the safety and efficacy of these new drugs that have the power to dramatically reduce LDL-C and associated cardiovascular diseases.
\end{abstract}

Keywords - PCSK9, LDL receptor, PCSK9 inhibitors, Cardiovascular Disease 
Pathology

\section{Abbreviations}

Apo B100

ACS

ASO

CAD

CVD

ER

$\mathrm{FH}$

HDL-C

HMGCR

LDL

LDL-C

LDLR

LNA

$\mathrm{mAb}$

PCSK9

SiRNA

SREBP
Apolipoprotein B

Acute Coronary Syndrome

Antisense Oligonucleotide

Coronary Artery Disease

Cardiovascular Disease

Endoplasmic Reticulum

Familial Hypercholesterolemia

High Density Lipoprotein Cholesterol

3-Hydroxy-3-Methylglutaryl-CoA Reductase

Low Density Lipoprotein

Low Density Lipoprotein Cholesterol

Low Density Lipoprotein Receptor

Locked Nucleic Acid

Monoclonal Antibody

Proprotein Convertase Subtilisin/kexin Type 9

Small Interfering Ribonucleic Acid

Sterol Regulatory Element-Binding Proteins 
Pathology

\section{Introduction}

Familial hypercholesterolemia (FH) is an autosomal dominant condition characterized by elevated plasma LDL-C levels, which are typically above the 95th percentile for age and sex. Molecular defects in the gene encoding the LDL receptor (LDLR) are identified in the vast majority of FH patients. ${ }^{1,2}$ Approximately $5 \%$ of individuals with an FH phenotype carry mutations in the ligand-binding domain of apolipoprotein B (ApoB), the protein component of LDL particle that interacts with the LDLR. ${ }^{3}$ Fifteen years ago, genetic defects in PCSK9 have been associated with the hypercholesterolemic phenotype in less than $1 \%$ of $\mathrm{FH}$ families. ${ }^{4}$ The unique mode of action of PCSK9 as an inhibitor of the LDLR has led to the successful development of a novel class of hypocholesterolemic agents: the PCSK9 inhibitors. We here review the biology of PCSK9, and the most significant pioneering preclinical studies that have paved the way for the development of PCSK9 inhibitors in clinical trials.

\section{The biology of PCSK9}

2.1 A unique protease - PCSK9 is a serine protease of the subtilase family mainly expressed in the liver and to a much lower extent in the intestine, the kidney, and the brain. It was initially thought to be involved in liver regeneration and neuronal differentiation. ${ }^{5}$ PCSK9 is synthesized as a $72 \mathrm{kDa}$ zymogen in the endoplasmic reticulum (ER). It undergoes autocatalytic intramolecular processing at the FAQ ${ }_{152} \downarrow$ SIP site to form a $63 \mathrm{kDa}$ mature enzyme found in the endoplasmic reticulum (ER) and the Golgi apparatus. ${ }^{6,7}$ The signal peptide (residues 1-30) and the prodomain (residues 31-152) of PCSK9, precede a catalytic domain (residues 153-425) that contains the canonical $\mathrm{N}_{186}, \mathrm{H}_{226}$ and $\mathrm{S}_{386}$ catalytic triad as well as the oxyanion hole $\mathrm{N}_{317}$ residue, followed by a C-terminal domain (residues 425-692). Unlike other proprotein convertases that cleave either after basic amino acids and are related to Kexin (e.g. furin) or after hydrophobic residues such as the Site 1 Protease that is related to 
Pathology

Pyrolysin, PCSK9 is the only known proprotein convertase of this family that cleaves after non-basic amino acids and thereby is related to proteinase $\mathrm{K}$. The only known substrate for PCSK9 is pro-PCSK9 itself. ${ }^{8}$

In 2003, Abifadel and colleagues identified the $S_{127} R$ and $F_{216} \mathrm{~L}$ missense mutations in the gene encoding PCSK9 in two French families with FH, previously described as not carrying a mutation in the LDLR or ApoB genes. ${ }^{4}$ The PCSK9- $\mathrm{D}_{374} \mathrm{Y}$ missense mutation was subsequently reported in FH patients from Utah, Norway, and the United Kingdom. ${ }^{9,10}$ These mutations were later shown to be "gain of function" (GOF) mutations. The prevalence of PCSK9 GOF mutations is very low $(\approx 1 \%)$ compared with defects in LDLR $(\approx 90 \%)$ and ApoB $(\approx 5 \%)$. The risk of coronary artery disease $(\mathrm{CAD})$ associated with the PCSK9- $\mathrm{D}_{374} \mathrm{Y}$ variant is sharply increased, and exceeds the average risk associated with mutations in the LDLR gene. ${ }^{11,12}$

Large cohort studies have been undertaken to address the role of common PCSK9 sequence variations in lipid metabolism and CAD risk. In 2005, a causative association was established between two relatively common "loss-of-function" (LOF) mutations in PCSK9 and low plasma LDL-C levels. ${ }^{13}$ The individuals carrying these mutations (PCSK9-C679X or PCSK9$\mathrm{Y}_{142} \mathrm{X}$ ) exhibited LDL-C levels of $2.6 \pm 1.1 \mathrm{mmol} / \mathrm{L}$, compared with $3.6 \pm 1.1 \mathrm{mmol} / \mathrm{l}$ for non-carriers, which was accompanied by an astonishing $88 \%$ reduction in global coronary heart disease risk. ${ }^{14}$ No other safety concerns were identified in this patient population. Likewise, persons of European descent carrying the PCSK9-R ${ }_{46} \mathrm{~L}$ LOF mutation exhibited LDL-C levels of $3.0 \pm 0.9 \mathrm{mmol} / \mathrm{L}$, compared with $3.5 \pm 1.0 \mathrm{mmol} / \mathrm{L}$ for non-carriers, which was accompanied by a $47 \%$ reduction in global coronary heart disease risk. ${ }^{14}$ As a result of these landmark observations, PCSK9 has become a very attractive drug target and the subject of intensive research. 
Pathology

2.2 A regulator of LDLR abundance at the cell surface - Besides FH genetic studies, the first evidence for a role for PCSK9 in cholesterol metabolism was a down regulation of PCSK9 hepatic expression observed in cholesterol fed mice. ${ }^{15}$ PCSK9 gene expression was upregulated in mice overexpressing SREBP, a transcription factor activated by low levels of intracellular cholesterol, and in cultured hepatocytes depleted of cholesterol by statin treatment. ${ }^{16,17}$ Definitive evidence for a direct role for PCSK9 in lipoprotein metabolism was provided by a series of studies showing that adenoviral-mediated overexpression of PCSK9 promotes the accumulation of LDL in the plasma of control mice but not in that of LDLR deficient animals. ${ }^{18,19}$ This was associated with decreased hepatic LDLR levels in mice overexpressing PCSK9.

The molecular mechanism by which PCSK9 modulates LDLR expression is not transcriptional. ${ }^{17,20}$ The overexpression of PCSK9 in HepG2 cells accelerates the intracellular degradation of the mature LDLR via a non-proteasomal mechanism. ${ }^{20,21}$ PCSK9 is in fact a secreted protein that binds to the LDLR and is subsequently internalized by the receptor, which in turn enhances its degradation in endo/lysosomal vesicles (Figure 1). ${ }^{22,23}$ Thus, exogenous PCSK9 decreases cell surface LDLR expression and PCSK9 is internalized in a manner almost totally dependent upon the LDLR itself in vitro. PCSK9 acts as a secreted protein in vivo, since secreted PCSK9 derived from a PCSK9 transgenic mouse is able to decrease hepatic LDLR expression in a parabiosed recipient wild-type animal, thereby increasing its plasma LDL levels. $^{22}$

The cleavage of the prodomain is required for PCSK9 maturation and secretion. ${ }^{23,24}$ This was demonstrated by experiments where the prodomain and the catalytically inactive $62 \mathrm{kDa}$ PCSK9 moiety were co-expressed, allowing the exit of a non-covalently bound PCSK9/prodomain complex from the endoplasmic reticulum to the Golgi complex and along the secretory pathway, which ultimately promoted LDLR degradation. ${ }^{25-28}$ After cleavage, 
Pathology

the prodomain forms hydrogen bonds with key amino acids of the catalytic domain, thereby preventing access of other potential substrates to the catalytic pocket of PCSK9. ${ }^{29,30}$ The ability of PCSK9 to promote LDLR degradation is, therefore, independent of its catalytic activity, indicating that PCSK9 functions as a chaperone, a mode of action that is unique among serine protease.

The region where secreted PCSK9 interacts with the extracellular domain of the LDLR is located in the first epidermal growth factor-like repeat homology domain (EGFA) of the LDLR. $^{30,31}$ At the plasma membrane (i.e. at neutral $\mathrm{pH}$ ), the catalytic domain of PCSK9 interacts with the EGFA domain of the receptor. After endocytosis (i.e. at the acidic $\mathrm{pH}$ of endosomes), the affinity between the receptor and PCSK9 is much higher than that observed at neutral $\mathrm{pH}^{29,32}$ The prodomain of PCSK9 establishes additional salt bridges with the receptor, and as a result PCSK9 locks the LDLR in an extended (or open) conformation. The failure of the receptor to adopt a closed conformation in the endosome precludes normal recycling to the plasma membrane and targets the LDLR for lysosomal degradation (Figure 2). ${ }^{29-33}$

Despite these advances, the exact trafficking of the PCSK9/LDLR complex has not been fully elucidated. The PCSK9/LDLR complex can reach the lysosome via the extracellular endosome-lysosome route or alternatively via the golgi-lysosome pathway that requires a direct interaction between the LDLR and PCSK9 intracellularly. ${ }^{34,35}$ The description of one LDLR mutant insensitive to PCSK9 induced degradation via the extracellular but not via the intracellular route illustrates major differences between both pathways in terms of trafficking dynamics. ${ }^{36}$ The extracellular pathway appears to be favoured in the liver, since grp94, an endoplasmic reticulum (ER) resident protein expressed in this tissue prevents PCSK9 from interacting with the LDLR. In addition, grp74 prevents a direct interaction between PCSK9 loss-of-function variants that are retained in the ER. ${ }^{37}$ 
Pathology

2.3 Towards the development of PCSK9 inhibitors - Studies of individuals with PCSK9 LOF variants were pivotal for the efficacy and safety aspects of PCSK9 inhibitors development. Mendelian randomization studies have recently corroborated the causal relationship between PCSK9, LDL-C and CVD risk, by demonstrating that LOF variants in the PCSK9 gene have similar effect on CVD risk per unit change in LDL-C than LOF variants in 3-hydroxy-3methylglutaryl-coenzyme A reductase (HMGCR) gene. ${ }^{38-41}$ The relative high prevalence of PCSK9 LOF mutations in the population indicates that such mutations are compatible with normal health. Thus, individuals with PCSK9 nonsense mutations have similar body mass index, diabetes prevalence and hypertension prevalence compared to those without mutations. Most important was the identification of individuals with LOF mutations in both PCSK9 alleles. For instance, a compound heterozygous woman inherited the $\mathrm{Y}_{142} \mathrm{X}$ mutation from her mother and the c290_292 delGCC mutation from her father. The latter mutation deletes $\mathrm{R}_{97}$ and prevents autocatalytic cleavage and secretion of PCSK9. ${ }^{42}$ Her plasma PCSK9 was undetectable and her LDL-C level was $0.36 \mathrm{mmol} / \mathrm{L}$. She was healthy, fertile, normotensive, and college-educated, with normal liver and renal functions. Likewise, a handful of homozygous cases of PCSK9-R46L LOF have been reported. Compared with wild-type and heterozygotes, who display LDL-C levels of $3.75 \pm 0.03 \mathrm{mmol} / \mathrm{L}$ and $3.31 \pm 0.07 \mathrm{mmol} / \mathrm{L}$, respectively, homozygotes have LDL-C levels of $3.08 \pm 0.54 \mathrm{mmol} / \mathrm{L} .{ }^{43}$ In line with these observations, a Zimbabwean woman attending an antenatal clinic was found to be homozygous for the PCSK9-C 679 X LOF mutation. ${ }^{44}$ She had an LDL-C level of $0.4 \mathrm{mmol} / \mathrm{L}$ postpartum. Wild-type and PCSK9-C679X heterozygous women had LDL-C levels of $2.2 \pm$ $0.7 \mathrm{mmol} / \mathrm{L}$ and $1.6 \pm 0.5 \mathrm{mmol} / \mathrm{L}$, respectively. Overall, a complete or near-complete absence of PCSK9 resulting in very low levels of LDL-C does not appear deleterious in humans and is compatible with normal health.

Given the mode of action of PCSK9 as a circulating inhibitor of the LDLR, as well as the 
Pathology

apparent healthy profile of individuals with reduced or absent PCSK9 function, PCSK9 rapidly gained status of a very clean drug target to lower LDL-C in humans. This was further demonstrated in preclinical studies and clinical trials.

\section{Clinical implications}

3.1 Preclinical studies - PCSK9-knockout mice have approximately 2.8-fold higher hepatic LDLR expression and $42 \%$ to $48 \%$ lower total plasma cholesterol and lower apoB levels than wild-type animals. ${ }^{45}$ These mice are particularly sensitive to statins, and their LDL-C fractional catabolic rate is markedly increased compared with wild-type mice. Similar features are observed in hepatocyte-specific conditional PCSK9-knockout mice, which have $27 \%$ lower plasma cholesterol than controls. ${ }^{46}$ Compared with their respective controls, LDL$\mathrm{C}$ is reduced by $80 \%$ and $60 \%$ in the plasma of complete PCSK9-knockout and hepatocytespecific PCSK9-knockout mice, respectively. The lipoprotein profiles of LDLR-knockout mice and of PCSK9/LDLR double-knockout mice are nearly identical, further demonstrating that PCSK9 modulates circulating cholesterol levels exclusively via the LDLR. ${ }^{46}$ Importantly, PCSK9 deletion in mice reduces the incidence of atherosclerosis in an LDLR-dependent manner. PCSK9-knockout mice fed a Western-style diet are protected from cholesterol ester deposition in the aorta on the C57BL/6 (74\% reduction) as well as on the apoE-knockout (39\% reduction) backgrounds, but not on the LDLR-knockout background. ${ }^{47}$

On these bases, several drug development strategies have been tested to pharmacologically inhibit PCSK9. They primarily include gene silencing with small interfering RNAs (siRNAs) or antisense oligonucleotides (ASO), as well as monoclonal antibodies (mAbs). The administration of a PCSK9 ASO inhibitor for 6 weeks to mice fed a high-fat diet resulted in a 2-fold increase in hepatic LDLR expression as well as $38 \%$ and $50 \%$ reductions in LDL-C and apoB-100 levels, respectively. ${ }^{48}$ Likewise, reduction of PCSK9 mRNA in mice by a 
Pathology

locked nucleic acid ASO (LNA ASO) resulted in a 2.5- to 3-fold increase in hepatic LDLR expression. ${ }^{49}$ In monkeys, an LNA ASO targeting PCSK9 decreased circulating PCSK9 by $85 \%$, plasma LDL-C by $50 \%$, and apoB levels by $35 \% .{ }^{50}$ Modifying the LNA-ASO sequence to be specific for human PCSK9 demonstrated similar LDL-C reductions while having longer-lasting effects. PCSK9 gene silencing in monkeys has also been achieved using siRNA, which reduced total cholesterol levels by up to $60 \%$ three days post-injection. ${ }^{51}$

In mice, a single intravenous infusion of a mAb specific to PCSK9 reduced circulating nonHDL-C levels in a significant and dose-dependent manner. In monkeys, a dose of $10-\mathrm{mg} / \mathrm{kg}$ of a mAb that structurally mimics the EGFA domain of the LDLR reduced plasma LDL-C levels by up to $80 \%$ over 10 days. ${ }^{52} \mathrm{~A}$ mAb with a greater affinity for PCSK9 lowered LDLC by $45 \%$ at the $1-\mathrm{mg} / \mathrm{kg}$ dose in healthy rhesus monkeys. ${ }^{53}$ In combination with simvastatin, this mAb lowered LDL-C by $40 \%$ in a group of monkeys with the metabolic syndrome. ${ }^{53} \mathrm{~A}$ $\mathrm{mAb}$, directed against the LDLR-EGFA binding domain of PCSK9 dose-dependently reduced LDL-C in humanized mice and nonhuman primates. ${ }^{54}$ The effects were similar when the animals were fed a high-fat diet, with a $64 \%$ reduction of LDL-C observed on day 3 postinjection. ${ }^{55}$ When administered with simvastatin, this $\mathrm{mAb}$ produced an additional $65 \%$ reduction in LDL-C levels. ${ }^{55}$ When modified to escape degradation, this mAb was found to be as potent as its precursor in mice and monkeys, with a 2.8 -fold extended duration of maximum efficacy. ${ }^{56} \mathrm{~A}$ comprehensive view of the important preclinical studies mentioned hereabove is given in Table $\mathbf{I}$.

3.2 Clinical trials - Similar approaches to evaluate PCSK9 inhibition in humans have been tested. Initially the most promising approach was the use of fully human monoclonal antibodies to PCSK9. A single injection can lower PCSK9 levels by up to $100 \%$ for more than a week. Phase I/II clinical trials have been conducted by Amgen (compound AMG 145, 
Pathology

known today as evolocumab or Repatha) $)^{57-61}$ and by Sanofi/Regeneron (compound SAR236553/REGN727 known today as alirocumab or Praluent). ${ }^{62-65}$ A humanized antiPCSK9 antibody (compound PF-4950615/RN-316, known as bococizumab) was developed by Pfizer-Rinat. ${ }^{66}$ All phase I demonstrated safety and efficacy. In phase II, a reduction between $60-70 \%$ of LDL-C was confirmed, especially when subcutaneous injections were performed every 2 weeks. No significant side effects were observed, except possible local reaction to the injection site. Phase I and II clinical trials have been reviewed in detail elsewhere. ${ }^{67,68}$ Three large phase III programs with the new PCSK9 antibodies were subsequently undertaken: the FOURIER program with evolocumab, ${ }^{69}$ the ODYSSEY program with alirocumab, ${ }^{70}$ and the bococizumab program (SPIRE 1 and 2). ${ }^{66}$ The main objective of these studies was to evaluate the effect of PCSK9 inhibition on the occurrence of CV events (composite endpoint of coronary heart death, non-fatal myocardial infarction, fatal and non-fatal stroke, unstable angina requiring hospitalization) in patients with acute coronary syndrome (ACS). These trials have unequivocally shown that PCSK9 inhibitors robustly and safely lower LDL-C levels regardless of background lipid-lowering therapy and prevent CVD (Table II). ${ }^{40,71,72}$ The SPIRE program was however terminated, as anti-drug antibodies developed in a significant proportion of patients, likely because bococizumab is a humanized and not a fully human mAb like evolocumab and alirocumab. ${ }^{73}$

In addition to the two fully human monoclonal antibodies alirocumab and evolocumab, which sequester PCSK9 in the circulation and have been approved by regulating bodies and are now prescribed to patients in many countries, other approaches to PCSK9 inhibition such as the small interfering RNA (siRNA) inclisiran are in late-stage clinical development. ${ }^{74,75}$ These novel approaches to PCSK9 inhibition could have significant benefits compared to PCSK9inhibiting mAbs, such as two-yearly administration and lower costs of therapy. 
Pathology

\section{Conclusion}

The development of PCSK9 inhibitors underlines the advantages of a genetic-driven approach to identify novel drug targets. Discovered as the third gene causing of FH fifteen years ago, ${ }^{4}$ PCSK9 has become a very promising drug target. The elucidation of its original mode of action as a secreted factor able to bind the LDLR and subsequently target it for intracellular degradation, as well as the absence of health issues associated with reduced or absent PCSK9 function have led to the successful development of these inhibitors that dramatically lower circulating LDL-C levels but most importantly prevent cardiovascular events. 
Pathology

\section{Acknowledgements}

GL is a laureate of the French national project CHOPIN (CHolesterol Personalized Innovation) granted by the Agence Nationale de la Recherche (ANR-16-RHUS-0007).

\section{Conflicts of Interest}

GL has received research funding and honoraria from Sanofi, Regeneron, Amgen, Affiris, Pfizer, and Nyrada Inc related to the development of PCSK9 inhibitors. 


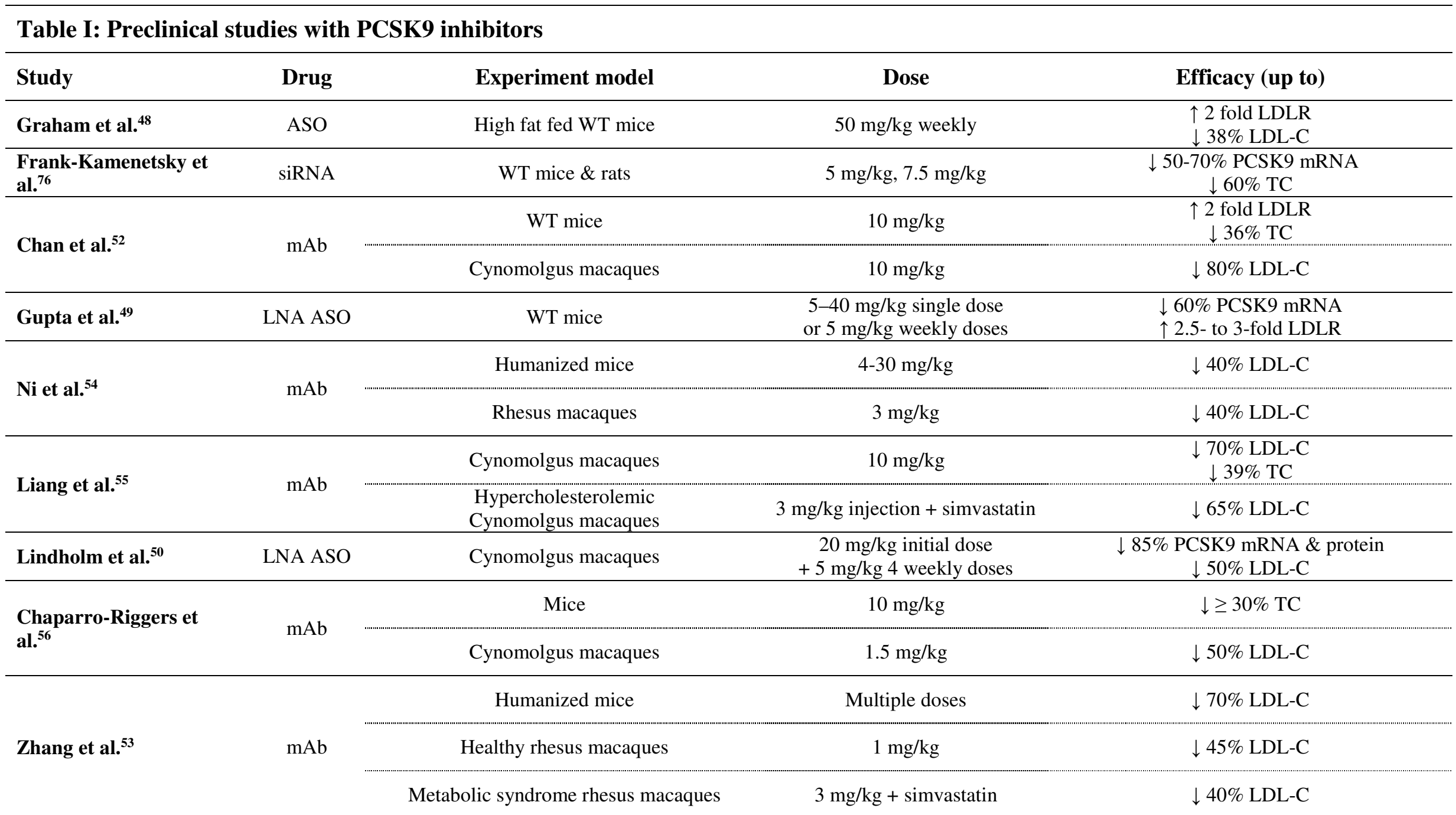

ASO, Antisense oligonucleotide; LDLR, Low density lipoprotein receptor; LDL-C, Low density lipoprotein-cholesterol; LNA, Locked nucleic acid; mAb, Monoclonal antibody; mRNA, Messenger ribonucleic acid; TC, Total cholesterol; WT, Wild-type. 


\section{Table II: Clinical trials}

\begin{tabular}{|c|c|c|c|c|c|c|c|c|}
\hline \multirow[b]{2}{*}{ Drug name } & \multirow[b]{2}{*}{$\begin{array}{l}\text { Patients } \\
\text { enrolled }\end{array}$} & \multirow[b]{2}{*}{ Trial design } & \multirow[b]{2}{*}{ Dosage } & \multicolumn{4}{|c|}{ Main findings } & \multirow[b]{2}{*}{ Reference } \\
\hline & & & & $\begin{array}{c}\text { Change of } \\
\text { LDL-C }\end{array}$ & CV events & $\begin{array}{c}\text { Proportion of } \\
\text { patients with } \\
\text { LDL-C }<70 \mathrm{mg} / \mathrm{dL}\end{array}$ & Side effects & \\
\hline Bococizumab & $\begin{array}{l}27438 \text { patients } \\
\text { at high CVD } \\
\text { risk }\end{array}$ & $\begin{array}{c}\mathrm{ST}+\mathrm{mAb} \\
\text { vs. } \mathrm{ST}+\text { placebo }\end{array}$ & $150 \mathrm{Q} 2 \mathrm{~W}$ & $\begin{array}{c}\downarrow 59 \% \text { vs. } \\
\text { ST }+ \text { placebo }\end{array}$ & $\begin{array}{c}\mathrm{ST}+\mathrm{mAb} \rightarrow 1.72 \% \\
\mathrm{ST}+\text { placebo } \rightarrow 1.88 \%\end{array}$ & 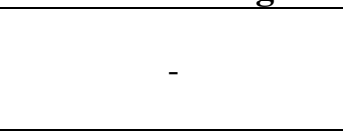 & $\begin{array}{c}\mathrm{ST}+\mathrm{mAb} \rightarrow 64 \% \\
\mathrm{ST}+\text { placebo } \rightarrow 61 \%\end{array}$ & $\begin{array}{l}\text { Ridker et } \\
\text { al. }^{72}\end{array}$ \\
\hline Alirocumab & $\begin{array}{c}2341 \text { patients } \\
\text { at high CVD } \\
\text { risk }\end{array}$ & $\begin{array}{c}\quad \mathrm{ST}+\mathrm{mAb} \\
\text { vs. } \mathrm{ST}+\text { placebo }\end{array}$ & $150 \mathrm{mg}$ Q2W & $\begin{array}{c}\downarrow 62 \% \text { vs. } \\
\text { ST + placebo }\end{array}$ & $\begin{array}{c}\mathrm{ST}+\mathrm{mAb} \rightarrow 1.7 \% \\
\mathrm{ST}+\text { placebo } \rightarrow 3.3 \%\end{array}$ & $\begin{array}{c}\mathrm{ST}+\mathrm{mAb} \rightarrow 79 \% \\
\mathrm{ST}+\text { placebo } \rightarrow 8 \%\end{array}$ & $\begin{array}{c}\mathrm{ST}+\mathrm{mAb} \rightarrow 81 \% \\
\mathrm{ST}+\text { placebo } \rightarrow 82 \%\end{array}$ & $\begin{array}{l}\text { Robinson et } \\
\text { al. }^{78}\end{array}$ \\
\hline Evolocumab & 4465 patients & $\begin{array}{c}\mathrm{ST}+\mathrm{mAb} \\
\text { vs. } \mathrm{ST}+\text { placebo }\end{array}$ & $\begin{array}{l}140 \mathrm{mg} \mathrm{Q} 2 \mathrm{~W} \\
\text { or } 420 \mathrm{mg} \text { QM }\end{array}$ & $\begin{array}{c}\downarrow 61 \% \text { vs. } \\
\text { ST }+ \text { placebo }\end{array}$ & $\begin{array}{c}\mathrm{ST}+\mathrm{mAb} \rightarrow 0.95 \% \\
\mathrm{ST}+\text { placebo } \rightarrow 2.18 \%\end{array}$ & $\begin{array}{c}\mathrm{ST}+\mathrm{mAb} \rightarrow 74 \% \\
\mathrm{ST}+\text { placebo } \rightarrow 4 \%\end{array}$ & $\begin{array}{c}\mathrm{ST}+\mathrm{mAb} \rightarrow 69 \% \\
\mathrm{ST}+\text { placebo } \rightarrow 65 \%\end{array}$ & $\begin{array}{l}\text { Sabatine et } \\
\quad \text { al. } .^{77}\end{array}$ \\
\hline Evolocumab & $\begin{array}{l}27564 \text { patients } \\
\text { with ASCVD }\end{array}$ & $\begin{array}{c}\mathrm{ST}+\mathrm{mAb} \\
\text { vs. ST + placebo }\end{array}$ & $\begin{array}{c}140 \mathrm{mg} \text { Q2W } \\
\text { or } 420 \mathrm{mg} \text { QM }\end{array}$ & $\begin{array}{c}\downarrow 59 \% \text { vs. } \\
\text { ST }+ \text { placebo }\end{array}$ & $\begin{array}{c}\mathrm{ST}+\mathrm{mAb} \rightarrow 7.9 \% \\
\mathrm{ST}+\text { placebo } \rightarrow 9.9 \%\end{array}$ & $\begin{array}{c}\mathrm{ST}+\mathrm{mAb} \rightarrow 87 \% \\
\mathrm{ST}+\text { placebo } \rightarrow 18 \%\end{array}$ & $\begin{array}{c}\mathrm{ST}+\mathrm{mAb} \rightarrow 77 \% \\
\mathrm{ST}+\text { placebo } \rightarrow 77 \%\end{array}$ & $\begin{array}{l}\text { Sabatine et } \\
\text { al. }^{71}\end{array}$ \\
\hline Inclisiran & 501 patients & $\begin{array}{c}\mathrm{ST}+\mathrm{SiRNA} \\
\text { vs. ST + placebo }\end{array}$ & $\begin{array}{c}\text { Single dose } \\
\text { (200-500 mg) or } \\
\text { two doses (100- } \\
300 \mathrm{mg})\end{array}$ & $\begin{array}{c}\text { Single dose: } \\
\downarrow 28-42 \% \\
\text { Two doses: } \\
\downarrow 35-53 \%\end{array}$ & - & $\mathrm{ST}+\mathrm{SiRNA} \rightarrow 66 \%$ & $\begin{array}{l}\mathrm{ST}+\mathrm{SiRNA} \rightarrow 76 \% \\
\mathrm{ST}+\text { placebo } \rightarrow 76 \%\end{array}$ & Ray et al. ${ }^{79}$ \\
\hline
\end{tabular}

CVD, Cardiovascular disease; mAb, Monoclonal antibody; Q2W, Every two weeks; QM, Every month; ST, Standard therapy (Maximal tolerated dose of statin \pm ezetimibe). 
Pathology

FIGURE 1: PCSK9 targets the LDLR toward endo-lysosomal degradation. Human dermal fibroblasts were grown in serum depleted culture conditions in the presence of 10mgmL mevastatin to maximally upregulate LDLR expression. Recombinant PCSK9 (300 $\mathrm{ng} / \mathrm{mL}$ ) or vehicle control was added to the culture medium for 10 minutes. Fibroblasts were then fixed, permeabilized and visualized by confocal microscopy using fluorescent antibodies for the LDLR [clone C7 at 4mg/mL (in red)], and Rab5 [PA3-915 at 1mg/mL (in green)] a specific marker of endolysosomes. Nuclei were counterstained with DAPI (in blue). Arrows indicate the colocalization of LDLR within endo-lysosomes. Scale $1 \mathrm{~mm}$.

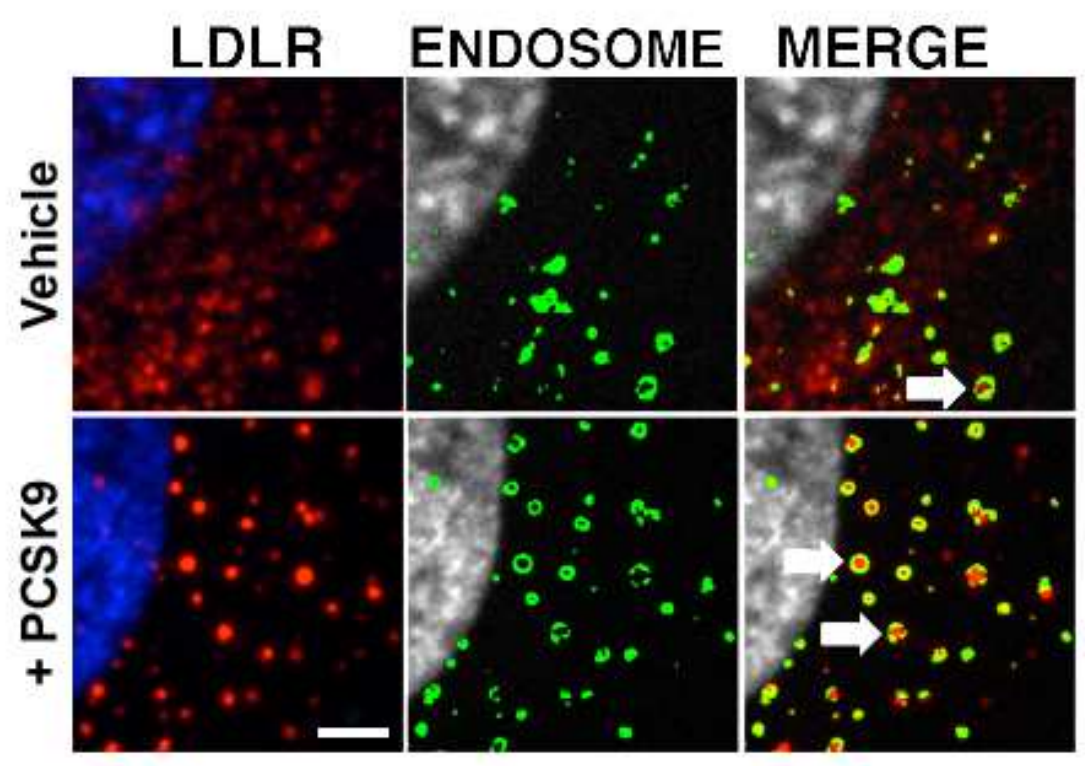


FIGURE 2: Schematic representation of PCSK9 mode of action. When internalized by the LDLR, PCSK9 prevents normal recycling of the receptor back to the cell surface (X). The LDLR is routed to the lysosome and degraded.

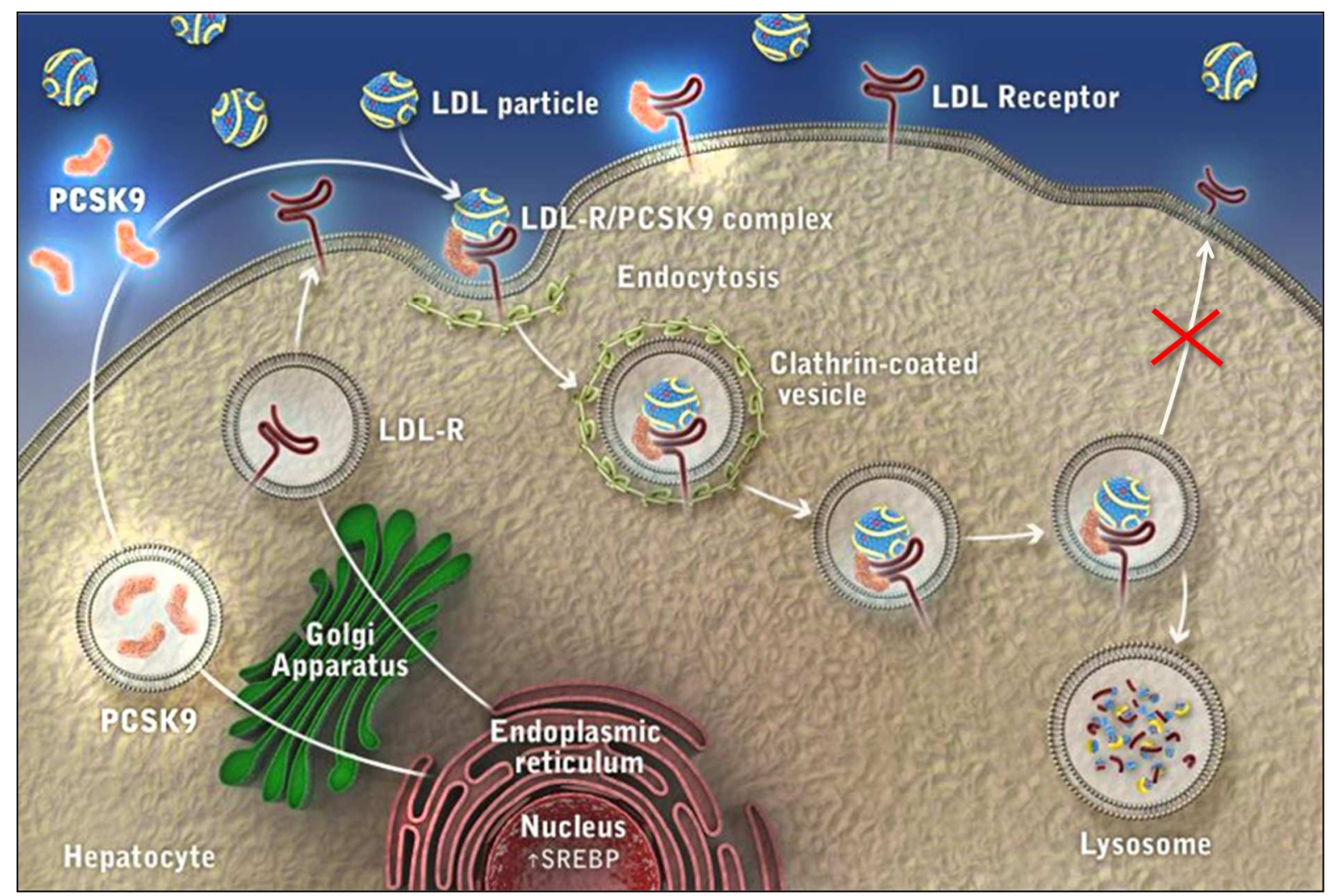




\section{References}

1. Hobbs HH, Brown MS, Goldstein JL. Molecular genetics of the LDL receptor gene in familial hypercholesterolemia. Hum Mutat 1992;1:445-466.

2. Soutar AK, Naoumova RP. Mechanisms of disease: genetic causes of familial hypercholesterolemia. Nat Clin Pract Cardiovasc Med 2007;4:214-225.

3. Innerarity TL, Mahley RW, Weisgraber KH, Bersot TP, Krauss RM, Vega GL, Grundy SM, Friedl W, Davignon J, McCarthy BJ. Familial defective apolipoprotein B-100: a mutation of apolipoprotein B that causes hypercholesterolemia. J Lipid Res 1990;31:1337-1349.

4. Abifadel M, Varret M, Rabès J-P, Allard D, Ouguerram K, Devillers M, Cruaud C, Benjannet S, Wickham L, Erlich D, Derré A, Villéger L, Farnier M, Beucler I, Bruckert E, Chambaz J, Chanu B, Lecerf J-M, Luc G, Moulin P, Weissenbach J, Prat A, Krempf M, Junien C, Seidah NG, Boileau C. Mutations in PCSK9 cause autosomal dominant hypercholesterolemia. Nat Genet 2003;34:154-156.

5. Seidah NG, Benjannet S, Wickham L, Marcinkiewicz J, Jasmin SB, Stifani S, Basak A, Prat A, Chretien M. The secretory proprotein convertase neural apoptosis-regulated convertase 1 (NARC-1): liver regeneration and neuronal differentiation. Proc Natl Acad Sci U S A 2003;100:928-933.

6. Naureckiene S, Ma L, Sreekumar K, Purandare U, Lo CF, Huang Y, Chiang LW, Grenier JM, Ozenberger BA, Jacobsen JS, Kennedy JD, DiStefano PS, Wood A, Bingham B. Functional characterization of Narc 1, a novel proteinase related to proteinase K. Arch Biochem Biophys 2003;420:55-67.

7. Benjannet S, Rhainds D, Essalmani R, Mayne J, Wickham L, Jin W, Asselin M-C, Hamelin J, Varret M, Allard D, Trillard M, Abifadel M, Tebon A, Attie AD, Rader DJ, Boileau C, Brissette L, Chrétien M, Prat A, Seidah NG. NARC-1/PCSK9 and its natural mutants: zymogen cleavage and effects on the low density lipoprotein (LDL) receptor and LDL cholesterol. J Biol Chem 2004;279:48865-48875.

8. Lambert G, Sjouke B, Choque B, Kastelein JJP, Hovingh GK. The PCSK9 decade. J Lipid Res 2012;53:2515-2524.

9. Timms KM, Wagner S, Samuels ME, Forbey K, Goldfine H, Jammulapati S, Skolnick MH, Hopkins PN, Hunt SC, Shattuck DM. A mutation in PCSK9 causing autosomal-dominant hypercholesterolemia in a Utah pedigree. Hum Genet 2004;114:349-353.

10. Leren TP. Mutations in the PCSK9 gene in Norwegian subjects with autosomal dominant hypercholesterolemia. Clin Genet 2004;65:419-422.

11. Naoumova RP, Tosi I, Patel D, Neuwirth C, Horswell SD, Marais AD, Heyningen C van, Soutar AK. Severe hypercholesterolemia in four British families with the D374Y mutation in the PCSK9 gene: long-term follow-up and treatment response. Arterioscler Thromb Vasc Biol 2005;25:2654-2660.

12. Humphries SE, Whittall RA, Hubbart CS, Maplebeck S, Cooper JA, Soutar AK, Naoumova R, Thompson GR, Seed M, Durrington PN, Miller JP, Betteridge DJB, Neil H a. W, Simon Broome Familial Hyperlipidaemia Register Group and Scientific Steering Committee. Genetic causes of familial hypercholesterolaemia in patients in the UK: relation to plasma lipid levels and coronary heart disease risk. J Med Genet 2006;43:943-949. 
Pathology

13. Cohen J, Pertsemlidis A, Kotowski IK, Graham R, Garcia CK, Hobbs HH. Low LDL cholesterol in individuals of African descent resulting from frequent nonsense mutations in PCSK9. Nat Genet 2005;37:161-165.

14. Cohen JC, Boerwinkle E, Mosley TH, Hobbs HH. Sequence variations in PCSK9, low LDL, and protection against coronary heart disease. N Engl J Med 2006;354:1264-1272.

15. Horton JD, Shah NA, Warrington JA, Anderson NN, Park SW, Brown MS, Goldstein JL. Combined analysis of oligonucleotide microarray data from transgenic and knockout mice identifies direct SREBP target genes. Proc Natl Acad Sci U S A 2003;100:12027-12032.

16. Dubuc G, Chamberland A, Wassef H, Davignon J, Seidah NG, Bernier L, Prat A. Statins upregulate PCSK9, the gene encoding the proprotein convertase neural apoptosis-regulated convertase-1 implicated in familial hypercholesterolemia. Arterioscler Thromb Vasc Biol 2004;24:1454-1459.

17. Park SW, Moon Y-A, Horton JD. Post-transcriptional regulation of low density lipoprotein receptor protein by proprotein convertase subtilisin/kexin type 9a in mouse liver. J Biol Chem 2004;279:50630-50638.

18. Maxwell KN, Breslow JL. Adenoviral-mediated expression of Pcsk9 in mice results in a lowdensity lipoprotein receptor knockout phenotype. Proc Natl Acad Sci U S A 2004;101:71007105.

19. Lalanne F, Lambert G, Amar MJA, Chétiveaux M, Zaïr Y, Jarnoux A-L, Ouguerram K, Friburg J, Seidah NG, Brewer HB, Krempf M, Costet P. Wild-type PCSK9 inhibits LDL clearance but does not affect apoB-containing lipoprotein production in mouse and cultured cells. J Lipid Res 2005;46:1312-1319.

20. Maxwell KN, Fisher EA, Breslow JL. Overexpression of PCSK9 accelerates the degradation of the LDLR in a post-endoplasmic reticulum compartment. Proc Natl Acad Sci U S A 2005;102:2069-2074.

21. Cameron J, Holla ØL, Ranheim T, Kulseth MA, Berge KE, Leren TP. Effect of mutations in the PCSK9 gene on the cell surface LDL receptors. Hum Mol Genet 2006;15:1551-1558.

22. Lagace TA, Curtis DE, Garuti R, McNutt MC, Park SW, Prather HB, Anderson NN, Ho YK, Hammer RE, Horton JD. Secreted PCSK9 decreases the number of LDL receptors in hepatocytes and in livers of parabiotic mice. J Clin Invest 2006;116:2995-3005.

23. Nassoury N, Blasiole DA, Tebon Oler A, Benjannet S, Hamelin J, Poupon V, McPherson PS, Attie AD, Prat A, Seidah NG. The cellular trafficking of the secretory proprotein convertase PCSK9 and its dependence on the LDLR. Traffic Cph Den 2007;8:718-732.

24. Qian Y-W, Schmidt RJ, Zhang Y, Chu S, Lin A, Wang H, Wang X, Beyer TP, Bensch WR, Li W, Ehsani ME, Lu D, Konrad RJ, Eacho PI, Moller DE, Karathanasis SK, Cao G. Secreted PCSK9 downregulates low density lipoprotein receptor through receptor-mediated endocytosis. J Lipid Res 2007;48:1488-1498.

25. McNutt MC, Lagace TA, Horton JD. Catalytic activity is not required for secreted PCSK9 to reduce low density lipoprotein receptors in HepG2 cells. J Biol Chem 2007;282:20799-20803.

26. Li J, Tumanut C, Gavigan J-A, Huang W-J, Hampton EN, Tumanut R, Suen KF, Trauger JW, Spraggon G, Lesley SA, Liau G, Yowe D, Harris JL. Secreted PCSK9 promotes LDL receptor degradation independently of proteolytic activity. Biochem J 2007;406:203-207. 
Pathology

27. Grefhorst A, McNutt MC, Lagace TA, Horton JD. Plasma PCSK9 preferentially reduces liver LDL receptors in mice. J Lipid Res 2008;49:1303-1311.

28. Schmidt RJ, Beyer TP, Bensch WR, Qian Y-W, Lin A, Kowala M, Alborn WE, Konrad RJ, Cao G. Secreted proprotein convertase subtilisin/kexin type 9 reduces both hepatic and extrahepatic low-density lipoprotein receptors in vivo. Biochem Biophys Res Commun 2008;370:634-640.

29. Cunningham D, Danley DE, Geoghegan KF, Griffor MC, Hawkins JL, Subashi TA, Varghese AH, Ammirati MJ, Culp JS, Hoth LR, Mansour MN, McGrath KM, Seddon AP, Shenolikar S, Stutzman-Engwall KJ, Warren LC, Xia D, Qiu X. Structural and biophysical studies of PCSK9 and its mutants linked to familial hypercholesterolemia. Nat Struct Mol Biol 2007;14:413-419.

30. Piper DE, Jackson S, Liu Q, Romanow WG, Shetterly S, Thibault ST, Shan B, Walker NPC. The crystal structure of PCSK9: a regulator of plasma LDL-cholesterol. Struct Lond Engl 1993 2007;15:545-552.

31. Zhang D-W, Lagace TA, Garuti R, Zhao Z, McDonald M, Horton JD, Cohen JC, Hobbs HH. Binding of proprotein convertase subtilisin/kexin type 9 to epidermal growth factor-like repeat A of low density lipoprotein receptor decreases receptor recycling and increases degradation. $J$ Biol Chem 2007;282:18602-18612.

32. Fisher TS, Lo Surdo P, Pandit S, Mattu M, Santoro JC, Wisniewski D, Cummings RT, Calzetta A, Cubbon RM, Fischer PA, Tarachandani A, De Francesco R, Wright SD, Sparrow CP, Carfi A, Sitlani A. Effects of $\mathrm{pH}$ and low density lipoprotein (LDL) on PCSK9-dependent LDL receptor regulation. J Biol Chem 2007;282:20502-20512.

33. Kwon HJ, Lagace TA, McNutt MC, Horton JD, Deisenhofer J. Molecular basis for LDL receptor recognition by PCSK9. Proc Natl Acad Sci U S A 2008;105:1820-1825.

34. Poirier S, Mamarbachi M, Chen W-T, Lee AS, Mayer G. GRP94 Regulates Circulating Cholesterol Levels through Blockade of PCSK9-Induced LDLR Degradation. Cell Rep 2015;13:2064-2071.

35. Poirier S, Hamouda HA, Villeneuve L, Demers A, Mayer G. Trafficking Dynamics of PCSK9Induced LDLR Degradation: Focus on Human PCSK9 Mutations and C-Terminal Domain. PloS One 2016;11:e0157230.

36. Susan-Resiga D, Girard E, Kiss RS, Essalmani R, Hamelin J, Asselin M-C, Awan Z, Butkinaree C, Fleury A, Soldera A, Dory YL, Baass A, Seidah NG. The Proprotein Convertase Subtilisin/Kexin Type 9-resistant R410S Low Density Lipoprotein Receptor Mutation: A NOVEL MECHANISM CAUSING FAMILIAL HYPERCHOLESTEROLEMIA. $J$ Biol Chem 2017;292:1573-1590.

37. Lebeau P, Platko K, Al-Hashimi AA, Byun JH, Lhoták Š, Holzapfel N, Gyulay G, Igdoura SA, Cool DR, Trigatti B, Seidah NG, Austin RC. Loss-of-function PCSK9 mutants evade the unfolded protein response sensor GRP78 and fail to induce endoplasmic reticulum stress when retained. J Biol Chem 2018;293:7329-7343.

38. Kent ST, Rosenson RS, Avery CL, Chen Y-DI, Correa A, Cummings SR, Cupples LA, Cushman M, Evans DS, Gudnason V, Harris TB, Howard G, Irvin MR, Judd SE, Jukema JW, Lange L, Levitan EB, Li X, Liu Y, Post WS, Postmus I, Psaty BM, Rotter JI, Safford MM, Sitlani CM, Smith AV, Stewart JD, Trompet S, Sun F, Vasan RS, et al. PCSK9 Loss-ofFunction Variants, Low-Density Lipoprotein Cholesterol, and Risk of Coronary Heart Disease and Stroke: Data From 9 Studies of Blacks and Whites. Circ Cardiovasc Genet 2017;10:e01632. 
Pathology

39. Lotta LA, Sharp SJ, Burgess S, Perry JRB, Stewart ID, Willems SM, Luan J 'an, Ardanaz E, Arriola L, Balkau B, Boeing H, Deloukas P, Forouhi NG, Franks PW, Grioni S, Kaaks R, Key TJ, Navarro C, Nilsson PM, Overvad K, Palli D, Panico S, Quirós J-R, Riboli E, Rolandsson O, Sacerdote C, Salamanca EC, Slimani N, Spijkerman AM, Tjonneland A, et al. Association Between Low-Density Lipoprotein Cholesterol-Lowering Genetic Variants and Risk of Type 2 Diabetes: A Meta-analysis. JAMA 2016;316:1383-1391.

40. Ference BA, Cannon CP, Landmesser U, Lüscher TF, Catapano AL, Ray KK. Reduction of low density lipoprotein-cholesterol and cardiovascular events with proprotein convertase subtilisinkexin type 9 (PCSK9) inhibitors and statins: an analysis of FOURIER, SPIRE, and the Cholesterol Treatment Trialists Collaboration. Eur Heart J 2018;39:2540-2545.

41. Ference BA, Robinson JG, Brook RD, Catapano AL, Chapman MJ, Neff DR, Voros S, Giugliano RP, Davey Smith G, Fazio S, Sabatine MS. Variation in PCSK9 and HMGCR and Risk of Cardiovascular Disease and Diabetes. N Engl J Med 2016;375:2144-2153.

42. Zhao Z, Tuakli-Wosornu Y, Lagace TA, Kinch L, Grishin NV, Horton JD, Cohen JC, Hobbs $\mathrm{HH}$. Molecular characterization of loss-of-function mutations in PCSK9 and identification of a compound heterozygote. Am J Hum Genet 2006;79:514-523.

43. Polisecki E, Peter I, Robertson M, McMahon AD, Ford I, Packard C, Shepherd J, Jukema JW, Blauw GJ, Westendorp RGJ, Craen AJM de, Trompet S, Buckley BM, Murphy MB, Ordovas JM, Schaefer EJ, PROSPER Study Group. Genetic variation at the PCSK9 locus moderately lowers low-density lipoprotein cholesterol levels, but does not significantly lower vascular disease risk in an elderly population. Atherosclerosis 2008;200:95-101.

44. Hooper AJ, Marais AD, Tanyanyiwa DM, Burnett JR. The C679X mutation in PCSK9 is present and lowers blood cholesterol in a Southern African population. Atherosclerosis 2007; 193:445-448.

45. Rashid S, Curtis DE, Garuti R, Anderson NN, Bashmakov Y, Ho YK, Hammer RE, Moon Y-A, Horton JD. Decreased plasma cholesterol and hypersensitivity to statins in mice lacking Pcsk9. Proc Natl Acad Sci U S A 2005;102:5374-5379.

46. Zaid A, Roubtsova A, Essalmani R, Marcinkiewicz J, Chamberland A, Hamelin J, Tremblay M, Jacques H, Jin W, Davignon J, Seidah NG, Prat A. Proprotein convertase subtilisin/kexin type 9 (PCSK9): hepatocyte-specific low-density lipoprotein receptor degradation and critical role in mouse liver regeneration. Hepatol Baltim Md 2008;48:646-654.

47. Denis M, Marcinkiewicz J, Zaid A, Gauthier D, Poirier S, Lazure C, Seidah NG, Prat A. Gene inactivation of proprotein convertase subtilisin/kexin type 9 reduces atherosclerosis in mice. Circulation 2012;125:894-901.

48. Graham MJ, Lemonidis KM, Whipple CP, Subramaniam A, Monia BP, Crooke ST, Crooke RM. Antisense inhibition of proprotein convertase subtilisin/kexin type 9 reduces serum LDL in hyperlipidemic mice. J Lipid Res 2007;48:763-767.

49. Gupta N, Fisker N, Asselin M-C, Lindholm M, Rosenbohm C, Ørum H, Elmén J, Seidah NG, Straarup EM. A locked nucleic acid antisense oligonucleotide (LNA) silences PCSK9 and enhances LDLR expression in vitro and in vivo. PloS One 2010;5:e10682.

50. Lindholm MW, Elmén J, Fisker N, Hansen HF, Persson R, Møller MR, Rosenbohm C, Ørum H, Straarup EM, Koch T. PCSK9 LNA antisense oligonucleotides induce sustained reduction of LDL cholesterol in nonhuman primates. Mol Ther J Am Soc Gene Ther 2012;20:376-381. 
51. Frank-Kamenetsky M, Grefhorst A, Anderson NN, Racie TS, Bramlage B, Akinc A, Butler D, Charisse K, Dorkin R, Fan Y, Gamba-Vitalo C, Hadwiger P, Jayaraman M, John M, Jayaprakash KN, Maier M, Nechev L, Rajeev KG, Read T, Röhl I, Soutschek J, Tan P, Wong J, Wang G, Zimmermann T, Fougerolles A de, Vornlocher H-P, Langer R, Anderson DG, Manoharan M, et al. Therapeutic RNAi targeting PCSK9 acutely lowers plasma cholesterol in rodents and LDL cholesterol in nonhuman primates. Proc Natl Acad Sci $U$ S A 2008;105:11915-11920.

52. Chan JCY, Piper DE, Cao Q, Liu D, King C, Wang W, Tang J, Liu Q, Higbee J, Xia Z, Di Y, Shetterly S, Arimura Z, Salomonis H, Romanow WG, Thibault ST, Zhang R, Cao P, Yang X-P, Yu T, Lu M, Retter MW, Kwon G, Henne K, Pan O, Tsai M-M, Fuchslocher B, Yang E, Zhou $\mathrm{L}$, Lee KJ, et al. A proprotein convertase subtilisin/kexin type 9 neutralizing antibody reduces serum cholesterol in mice and nonhuman primates. Proc Natl Acad Sci U S A 2009;106:98209825.

53. Zhang L, McCabe T, Condra JH, Ni YG, Peterson LB, Wang W, Strack AM, Wang F, Pandit S, Hammond H, Wood D, Lewis D, Rosa R, Mendoza V, Cumiskey AM, Johns DG, Hansen BC, Shen X, Geoghagen N, Jensen K, Zhu L, Wietecha K, Wisniewski D, Huang L, Zhao JZ, Ernst R, Hampton R, Haytko P, Ansbro F, Chilewski S, et al. An anti-PCSK9 antibody reduces LDLcholesterol on top of a statin and suppresses hepatocyte SREBP-regulated genes. Int J Biol Sci 2012;8:310-327.

54. Ni YG, Di Marco S, Condra JH, Peterson LB, Wang W, Wang F, Pandit S, Hammond HA, Rosa R, Cummings RT, Wood DD, Liu X, Bottomley MJ, Shen X, Cubbon RM, Wang S, Johns DG, Volpari C, Hamuro L, Chin J, Huang L, Zhao JZ, Vitelli S, Haytko P, Wisniewski D, Mitnaul LJ, Sparrow CP, Hubbard B, Carfí A, Sitlani A. A PCSK9-binding antibody that structurally mimics the EGF(A) domain of LDL-receptor reduces LDL cholesterol in vivo. $J$ Lipid Res 2011;52:78-86.

55. Liang H, Chaparro-Riggers J, Strop P, Geng T, Sutton JE, Tsai D, Bai L, Abdiche Y, Dilley J, Yu J, Wu S, Chin SM, Lee NA, Rossi A, Lin JC, Rajpal A, Pons J, Shelton DL. Proprotein convertase substilisin/kexin type 9 antagonism reduces low-density lipoprotein cholesterol in statin-treated hypercholesterolemic nonhuman primates. J Pharmacol Exp Ther 2012;340:228236.

56. Chaparro-Riggers J, Liang H, DeVay RM, Bai L, Sutton JE, Chen W, Geng T, Lindquist K, Casas MG, Boustany LM, Brown CL, Chabot J, Gomes B, Garzone P, Rossi A, Strop P, Shelton D, Pons J, Rajpal A. Increasing serum half-life and extending cholesterol lowering in vivo by engineering antibody with pH-sensitive binding to PCSK9. J Biol Chem 2012;287:11090-11097.

57. Dias CS, Shaywitz AJ, Wasserman SM, Smith BP, Gao B, Stolman DS, Crispino CP, Smirnakis KV, Emery MG, Colbert A, Gibbs JP, Retter MW, Cooke BP, Uy ST, Matson M, Stein EA. Effects of AMG 145 on low-density lipoprotein cholesterol levels: results from 2 randomized, double-blind, placebo-controlled, ascending-dose phase 1 studies in healthy volunteers and hypercholesterolemic subjects on statins. J Am Coll Cardiol 2012;60:1888-1898.

58. Sullivan D, Olsson AG, Scott R, Kim JB, Xue A, Gebski V, Wasserman SM, Stein EA. Effect of a monoclonal antibody to PCSK9 on low-density lipoprotein cholesterol levels in statinintolerant patients: the GAUSS randomized trial. JAMA 2012;308:2497-2506.

59. Raal F, Scott R, Somaratne R, Bridges I, Li G, Wasserman SM, Stein EA. Low-density lipoprotein cholesterol-lowering effects of AMG 145, a monoclonal antibody to proprotein convertase subtilisin/kexin type 9 serine protease in patients with heterozygous familial hypercholesterolemia: the Reduction of LDL-C with PCSK9 Inhibition in Heterozygous 
Pathology

Familial Hypercholesterolemia Disorder (RUTHERFORD) randomized trial. Circulation 2012;126:2408-2417.

60. Koren MJ, Scott R, Kim JB, Knusel B, Liu T, Lei L, Bolognese M, Wasserman SM. Efficacy, safety, and tolerability of a monoclonal antibody to proprotein convertase subtilisin/kexin type 9 as monotherapy in patients with hypercholesterolaemia (MENDEL): a randomised, double-blind, placebo-controlled, phase 2 study. Lancet Lond Engl 2012;380:1995-2006.

61. Giugliano RP, Desai NR, Kohli P, Rogers WJ, Somaratne R, Huang F, Liu T, Mohanavelu S, Hoffman EB, McDonald ST, Abrahamsen TE, Wasserman SM, Scott R, Sabatine MS, LAPLACE-TIMI 57 Investigators. Efficacy, safety, and tolerability of a monoclonal antibody to proprotein convertase subtilisin/kexin type 9 in combination with a statin in patients with hypercholesterolaemia (LAPLACE-TIMI 57): a randomised, placebo-controlled, dose-ranging, phase 2 study. Lancet Lond Engl 2012;380:2007-2017.

62. Stein EA, Mellis S, Yancopoulos GD, Stahl N, Logan D, Smith WB, Lisbon E, Gutierrez M, Webb C, Wu R, Du Y, Kranz T, Gasparino E, Swergold GD. Effect of a monoclonal antibody to PCSK9 on LDL cholesterol. N Engl J Med 2012;366:1108-1118.

63. McKenney JM, Koren MJ, Kereiakes DJ, Hanotin C, Ferrand A-C, Stein EA. Safety and efficacy of a monoclonal antibody to proprotein convertase subtilisin/kexin type 9 serine protease, SAR236553/REGN727, in patients with primary hypercholesterolemia receiving ongoing stable atorvastatin therapy. J Am Coll Cardiol 2012;59:2344-2353.

64. Stein EA, Gipe D, Bergeron J, Gaudet D, Weiss R, Dufour R, Wu R, Pordy R. Effect of a monoclonal antibody to PCSK9, REGN727/SAR236553, to reduce low-density lipoprotein cholesterol in patients with heterozygous familial hypercholesterolaemia on stable statin dose with or without ezetimibe therapy: a phase 2 randomised controlled trial. Lancet Lond Engl 2012;380:29-36.

65. Roth EM, McKenney JM, Hanotin C, Asset G, Stein EA. Atorvastatin with or without an antibody to PCSK9 in primary hypercholesterolemia. N Engl J Med 2012;367:1891-1900.

66. Ballantyne CM, Neutel J, Cropp A, Duggan W, Wang EQ, Plowchalk D, Sweeney K, Kaila N, Vincent J, Bays $\mathrm{H}$. Results of bococizumab, a monoclonal antibody against proprotein convertase subtilisin/kexin type 9, from a randomized, placebo-controlled, dose-ranging study in statin-treated subjects with hypercholesterolemia. Am J Cardiol 2015;115:1212-1221.

67. Stein EA, Raal F. Reduction of low-density lipoprotein cholesterol by monoclonal antibody inhibition of PCSK9. Annu Rev Med 2014;65:417-431.

68. Bergeron N, Phan BAP, Ding Y, Fong A, Krauss RM. Proprotein convertase subtilisin/kexin type 9 inhibition: a new therapeutic mechanism for reducing cardiovascular disease risk. Circulation 2015;132:1648-1666.

69. Sabatine MS, Giugliano RP, Wiviott SD, Raal FJ, Blom DJ, Robinson J, Ballantyne CM, Somaratne R, Legg J, Wasserman SM, Scott R, Koren MJ, Stein EA, Open-Label Study of Long-Term Evaluation against LDL Cholesterol (OSLER) Investigators. Efficacy and safety of evolocumab in reducing lipids and cardiovascular events. N Engl J Med 2015;372:1500-1509.

70. Robinson JG, Farnier M, Krempf M, Bergeron J, Luc G, Averna M, Stroes ES, Langslet G, Raal FJ, El Shahawy M, Koren MJ, Lepor NE, Lorenzato C, Pordy R, Chaudhari U, Kastelein JJP, ODYSSEY LONG TERM Investigators. Efficacy and safety of alirocumab in reducing lipids and cardiovascular events. $N$ Engl J Med 2015;372:1489-1499. 
Pathology

71. Sabatine MS, Giugliano RP, Keech AC, Honarpour N, Wiviott SD, Murphy SA, Kuder JF, Wang H, Liu T, Wasserman SM, Sever PS, Pedersen TR, FOURIER Steering Committee and Investigators. Evolocumab and Clinical Outcomes in Patients with Cardiovascular Disease. $N$ Engl J Med 2017;376:1713-1722.

72. Ridker PM, Revkin J, Amarenco P, Brunell R, Curto M, Civeira F, Flather M, Glynn RJ, Gregoire J, Jukema JW, Karpov Y, Kastelein JJP, Koenig W, Lorenzatti A, Manga P, Masiukiewicz U, Miller M, Mosterd A, Murin J, Nicolau JC, Nissen S, Ponikowski P, Santos RD, Schwartz PF, Soran H, White H, Wright RS, Vrablik M, Yunis C, Shear CL, et al. Cardiovascular Efficacy and Safety of Bococizumab in High-Risk Patients. $N$ Engl J Med 2017;376:1527-1539.

73. Ridker PM, Tardif J-C, Amarenco P, Duggan W, Glynn RJ, Jukema JW, Kastelein JJP, Kim AM, Koenig W, Nissen S, Revkin J, Rose LM, Santos RD, Schwartz PF, Shear CL, Yunis C, SPIRE Investigators. Lipid-Reduction Variability and Antidrug-Antibody Formation with Bococizumab. N Engl J Med 2017;376:1517-1526.

74. Fitzgerald K, White S, Borodovsky A, Bettencourt BR, Strahs A, Clausen V, Wijngaard P, Horton JD, Taubel J, Brooks A, Fernando C, Kauffman RS, Kallend D, Vaishnaw A, Simon A. A Highly Durable RNAi Therapeutic Inhibitor of PCSK9. N Engl J Med 2017;376:41-51.

75. Ray KK, Landmesser U, Leiter LA, Kallend D, Dufour R, Karakas M, Hall T, Troquay RPT, Turner T, Visseren FLJ, Wijngaard P, Wright RS, Kastelein JJP. Inclisiran in Patients at High Cardiovascular Risk with Elevated LDL Cholesterol. N Engl J Med 2017;376:1430-1440.

76. Frank-Kamenetsky M, Grefhorst A, Anderson NN, Racie TS, Bramlage B, Akinc A, Butler D, Charisse K, Dorkin R, Fan Y, Gamba-Vitalo C, Hadwiger P, Jayaraman M, John M, Jayaprakash KN, Maier M, Nechev L, Rajeev KG, Read T, Röhl I, Soutschek J, Tan P, Wong J, Wang G, Zimmermann T, Fougerolles A de, Vornlocher H-P, Langer R, Anderson DG, Manoharan M, et al. Therapeutic RNAi targeting PCSK9 acutely lowers plasma cholesterol in rodents and LDL cholesterol in nonhuman primates. Proc Natl Acad Sci U S A 2008;105:11915-11920.

77. Sabatine MS, Giugliano RP, Wiviott SD, Raal FJ, Blom DJ, Robinson J, Ballantyne CM, Somaratne R, Legg J, Wasserman SM, Scott R, Koren MJ, Stein EA, Open-Label Study of Long-Term Evaluation against LDL Cholesterol (OSLER) Investigators. Efficacy and safety of evolocumab in reducing lipids and cardiovascular events. N Engl J Med 2015;372:1500-1509.

78. Robinson JG, Farnier M, Krempf M, Bergeron J, Luc G, Averna M, Stroes ES, Langslet G, Raal FJ, El Shahawy M, Koren MJ, Lepor NE, Lorenzato C, Pordy R, Chaudhari U, Kastelein JJP, ODYSSEY LONG TERM Investigators. Efficacy and safety of alirocumab in reducing lipids and cardiovascular events. N Engl J Med 2015;372:1489-1499.

79. Ray KK, Landmesser U, Leiter LA, Kallend D, Dufour R, Karakas M, Hall T, Troquay RPT, Turner T, Visseren FLJ, Wijngaard P, Wright RS, Kastelein JJP. Inclisiran in Patients at High Cardiovascular Risk with Elevated LDL Cholesterol. N Engl J Med 2017;376:1430-1440. 